\title{
Bioactive Glass Efficacy in the Periodontal Healing of Intrabony Defects in Monkeys
}

\author{
José Henrique VILLAÇA ${ }^{1}$ \\ Arthur B. NOVAES Jr. ${ }^{1}$ \\ Sérgio Luís Scombatti de SOUZA ${ }^{1}$ \\ Mario TABA Jr. ${ }^{1}$ \\ Gustavo Otoboni MOLINA ${ }^{1}$ \\ Teresa Lúcia Lamano CARVALHO 2 \\ ${ }^{1}$ Department of Bucco-Maxillo-Facial Surgery and Traumatology and Periodontology, \\ ${ }^{2}$ Department of Morphology, Stomatology and Physiology, \\ Faculty of Dentistry of Ribeirão Preto, University of São Paulo, Ribeirão Preto, SP, Brazil
}

\begin{abstract}
The purpose of this study was the histomorphologic analysis of the efficacy of bioactive glass particles with a narrow size range (Biogran) in the periodontal healing of 2-wall intrabony defects in monkeys. The 2-wall defects were made in the mesial area of the left and right second premolars of four monkeys, filled with gutta-percha and, after 15 days, they were debrided and either naturally filled with coagulum (control) or implanted with bioactive glass (test). In the control sites, the junctional epithelium migrated up to the base of the defect. The presence of newly formed cementum was more significant in the test defects. Both control and test sites showed newly formed bone at the base of the defect. The test defects presented foci of newly formed bone around and within the glass particles localized in the middle third, distant from the defect walls. Histologic analysis showed that the $300-$ to $355-\mu \mathrm{m}$ bioactive glass particles aided new periodontal insertion. In conclusion, the tested bioactive glass had better healing potential than debridement only. The graft material showed a promising inhibition of apical migration of the junctional epithelium and greater cementum deposition on the radicular surface of the intrabony defects. The replacement of bioactive glass particles by new bone occurred due not only to an osteoconductive property, but also to an osteostimulatory capacity. Future investigations should evaluate this potential comparatively or together with other grafting materials, regenerative techniques and biological modifiers, as well as assess the longitudinal stability of the new attachment.
\end{abstract}

Key Words: new attachment, bioactive glass, bone grafting, intrabony defects, osteoconduction.

\section{INTRODUCTION}

The purpose of periodontal therapy is the regeneration of tissue that has been lost due to the progression of periodontal disease, i.e., reduction of periodontal pockets and regeneration of alveolar bone, cementum and periodontal attachment. Several materials have been introduced for bone grafts, i.e., autografts, allografts, xenografts and alloplastic grafts, but the currently available materials have not shown predictable periodontal regeneration.

The first studies on bioactive glass and the possibility of its application as a bone filling material were published in the 1970's and 1980's $(1,2)$. This glass was developed by Hench (3) and has a granule shape composed of $45 \% \mathrm{SiO}_{2}, 24.5 \% \mathrm{CaO}, 24.5 \% \mathrm{Na}_{2} \mathrm{O}$ and $6 \% \mathrm{P}_{2} \mathrm{O}_{5}$.

Several in vitro studies have shown the nontoxicity of bioactive glass, its positive influence on osteoblast culture (1), inhibitory capacity on fibroblast proliferation (4) and ability to form calcification foci in periodontal ligament fibroblasts (5). Histologic studies in animals have shown that bioactive glass implanted in non-periodontal sites is biocompatible and incorporates into the bone tissue thus producing an alkaline $\mathrm{pH}$ at the implantation site $(2,5)$. 
Zamet et al. (6) and Low et al. (7) reported good clinical results in intrabony defects in sites treated with a bioactive glass with a wide-size range of particles (Biogran; Orthovita Inc., Malvern, PA, USA) when compared to debridement. Park et al. (8) found similar results comparing a bioactive glass with a narrow-size range of particles (Perioglas; US Biomaterials Corporation, Alachua, FL, USA) to debridement.

A 300 - to $355-\mu \mathrm{m}$ particle size range presents better tissue responses, leading to bone regeneration by bone deposition into the cracks occurring in particles of these size (9). In particles larger than $355 \mu \mathrm{m}$, these cracks are not likely to occur or they would occur at a lower degree. Moreover, similar-sized particles have spaces among them even when they are well condensed, which may allow for cellular migration (9).

The purpose of this study was to investigate, by means of a histomorphologic analysis, the efficacy of a bioactive glass (Biogran) in the periodontal healing of standard 2-wall intrabony defects in monkeys.

\section{MATERIAL AND METHODS}

Four young male Cebus appela monkeys (weight 2.3-2.8 kg) were used. The animals were fasted the night before surgery. They were anesthetized with sodium thionembutal $(30 \mathrm{mg} / \mathrm{kg}$ body weight, ip) for all experimental procedures. During the experimental period, the animals were kept in individual cages with routine care and were fed bananas, yogurt, ration and eggs.

After anesthesia, extra- and intraoral asepsis with $0.12 \%$ chlorhexidine digluconate and prophylaxis, the right and left mandibular first premolars were extracted with forceps specially adapted to the size of the animal teeth. The flaps were sutured with 5-0 resorbable sutures.

Forty-five days later, the animals were anesthetized again and a mucoperiosteal flap was raised, lingually and buccally, from the mesial area of the canine to the distal area of the third premolar of both mandibular hemiarchs. In the area mesially to the right and left second premolars, standard 2-wall intrabony defects were made by the same operator with manual and rotary instruments and abundant sterile saline irrigation. The lingual walls of the defects were maintained. The depth of the defects was $3 \mathrm{~mm}$ and the mesiodistal distance was $2 \mathrm{~mm}$.
The teeth adjacent to the defects were scaled and root-planed to remove dental plaque, periodontal ligament fibers and cementum. The defects were filled with gutta-percha to prevent spontaneous regeneration and the flaps were sutured with 5-0 resorbable sutures.

Fifteen days after the defects were made, the animals were anesthetized again and mucoperiostea flaps were raised, as previously described. At this time, the gutta-percha was removed, the defects were debrided and the roots were scaled and planed with Gracey curettes. A notch was made on the root surface at the apical border of the bone defect with a $1 / 2$ round carbide bur.

The control defect made on the mesial side of the right second premolar was naturally filled with coagulum, while the test defect made on the mesial side of the left second premolar was filled with bioactive glass (Biogran). Once the defects were filled, the flaps were repositioned and sutured with 5-0 resorbable sutures.

The monkeys received 300,000 IU penicillin Gprocaine and penicillin-G potassic crystalline and streptomycin, im, $24 \mathrm{~h}$ before surgery and a second dose 4 days later. Immediately post surgery, $20 \mathrm{mg}$ of potassic diclofenac was administered (im). From this moment until sacrifice, the animals had their teeth cleaned weekly with a toothbrush and $0.12 \%$ chlorhexidine digluconate. Two animals, chosen at random, were sacrificed 50 days after filling the defects while the other two animals were sacrificed after 90 days.

The animals were anesthetized for sacrifice at the established intervals and, after thoracotomy, the right atrium was sectioned, a catheter was introduced into the left ventricle and $4 \mathrm{~L}$ of heparinized $0.9 \%$ saline solution was infused to wash the circulatory system. Afterwards, $4 \mathrm{~L}$ of neutral $10 \%$ formaldehyde was infused, the mandibles were dissected and two anatomic specimens with one defect and an adjacent tooth in each were obtained form each animal. After decalcification (10) and embedding in paraffin, 6- $\mu \mathrm{m}$ thick histologic sections cut in a mesiodistal direction were obtained and stained with hematoxylin-eosin (H\&E) and Masson trichrome.

Five central histologic sections, distant approximately $100 \mu \mathrm{m}$ from each other, were used for histologic analysis. The sections were examined with an H500-Hund Wetzlar optical microscope (Wilhelm, Wetzlar, Germany) and the images were captured by a CCD-Iris Sony video camera (Sony Corporation, 
Shinagawa, Tokyo, Japan) and transmitted to a computer with the UTHSCSA Image Tool 2.0 image-processing program (University of Texas, San Antonio, Texas, USA) for analysis of the periodontal healing. Statistical analysis was not done because of the small size of the sample. Histomorphometry was carried out to analyze the results of the study.

To evaluate epithelial migration, the distance from the notch to the most apical portion of the junctional epithelium was considered. This attempted to eliminate discrepancies that could occur because of the different degrees of gingival recession between control and test sites. To evaluate the cementum, the linear distance from the notch to the most coronal portion of cementum deposit was considered.

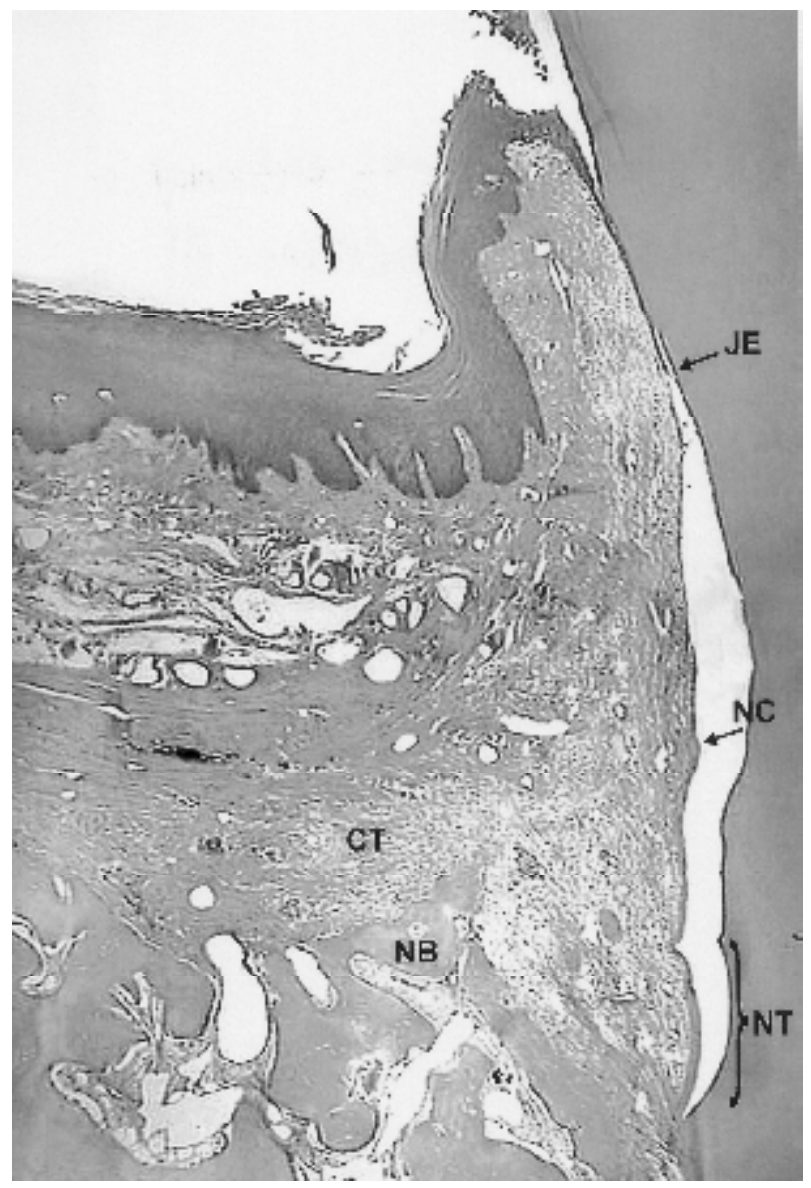

Figure 1. Mesiodistal histologic section of the control defect at 50 days. Observe junctional epithelium (JE), new cementum (NC) in the notch (NT) area slightly coronal to it and new bone (NB) formation in the most apical area. H\&E (original magnification $\mathrm{X} 22.5$ ). $\mathrm{CT}=$ connective tissue.

\section{Results}

\section{Histologic Findings}

\section{Days}

In the control defects, junctional epithelium migration occurred up to the area slightly coronal to the notch where the connective fibers were disposed parallel to the root surface (Fig. 1). New cementum was deposited within the notch and slightly coronal to this area. New bone formation was observed in the most apical area and the rest of the defect was filled with fibrous connective tissue rich in vessels and without inflammatory reaction.

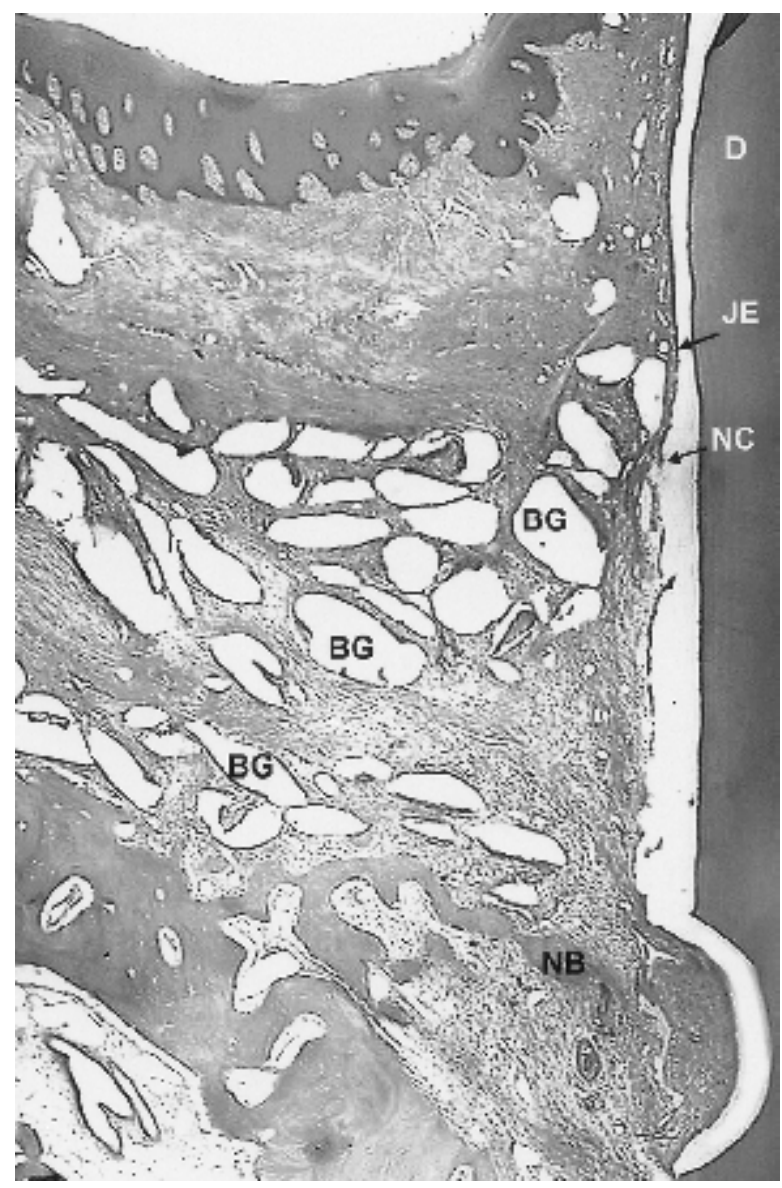

Figure 2. Mesiodistal histologic section of the test defect at 50 days. Observe junctional epithelium (JE), new cementum (NC) extending up to the surroundings of the $\mathrm{JE}$, bioactive glass particles (BG) and new bone (NB) formation in the area near the notch (NT). H\&E (original magnification X22.5). D = dentin. 
In the test defects, the junctional epithelium extended up to the point where the bioactive glass particles were located, without interposing between the root surface and the graft material. A regular cementum layer was seen deposited at the notch level on the root surface. Coronally to this area, the cementum layer was thin with irregular thickness and functionally oriented connective fibers inserted and extending up to the junctional epithelium. There was discreet new bone formation in the area near the notch and the defect wall. The bioactive glass particles located from the base up to the central portion of the defect were irregularly shaped, generally elongated and surrounded by fibrous connective tissue rich in vessels without inflammatory reaction (Fig. 2). Most of the particles localized in the central area of the defect had small superficial erosions

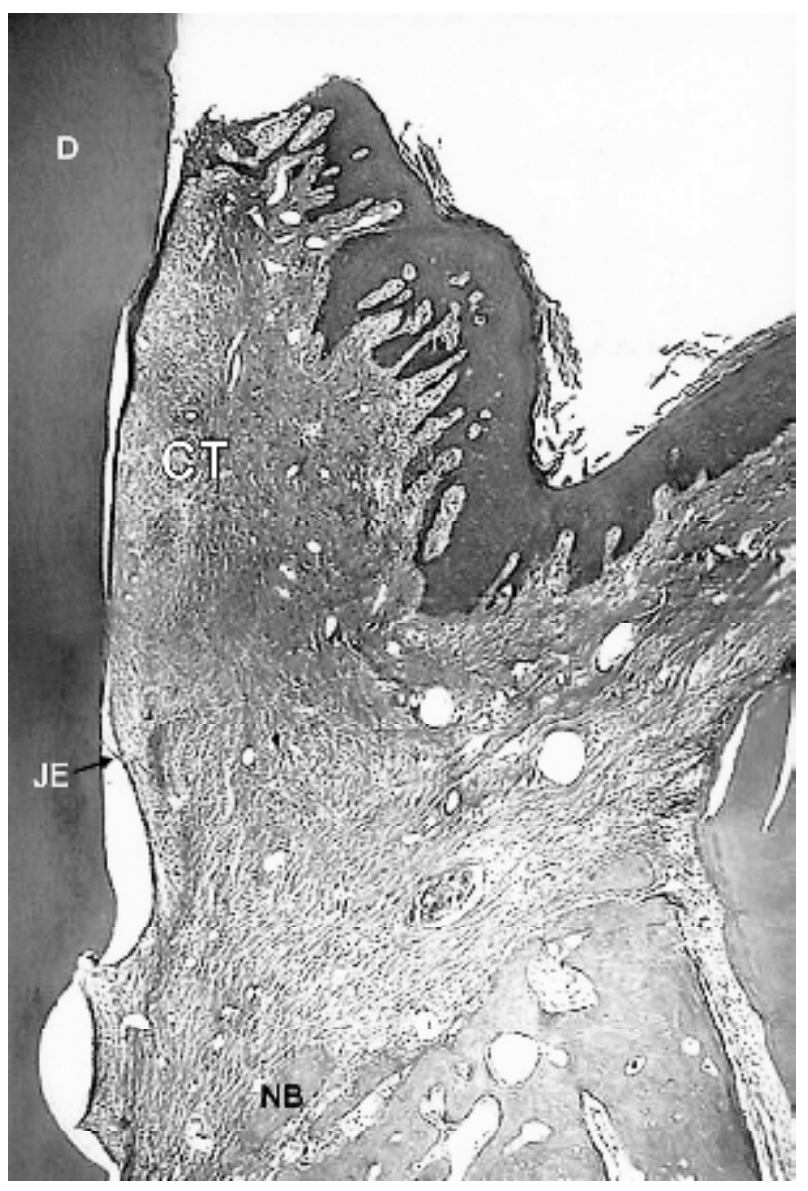

Figure 3. Mesiodistal histologic section of the control defect at 90 days. Observe long junctional epithelium (JE) and new bone (NB) formation in the apical area of the defect. There was no new cementum formation. Masson trichrome stain (original magnification X22.5). $\mathrm{CT}=$ connective tissue; $\mathrm{D}=$ dentin. or rare cracks, generally without newly formed tissue. Signs of bone deposit were observed near the defect walls, on their external surface and inside the cracks, which were already filled with osteoid tissue.

\section{Days}

In the control defects, cementum deposit was either absent or restricted to the notch. Connective fibers were seen parallel to root surface, separated by a

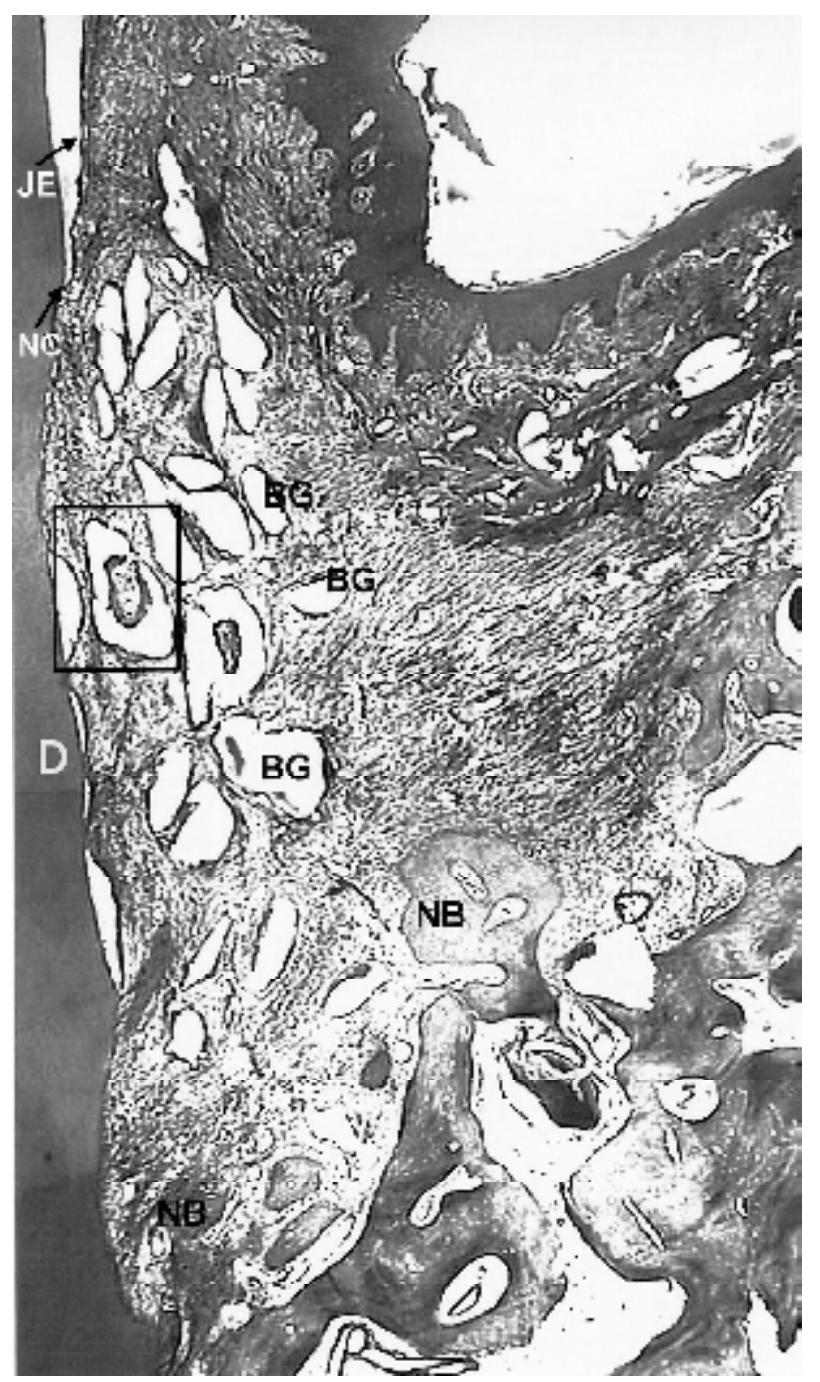

Figure 4. Mesiodistal histologic section of the test defect at 90 days. Observe junctional epithelium (JE), new cementum (NC) extending up to the surroundings of the JE, new bone (NB) formation in the apical area of the defect and in the notch, and NB in the bioactive glass particles (BG) in the middle third adjacent to the root surface, distant from the bone walls. Masson trichrome stain (original magnification X22.5). D = dentin. 
long junctional epithelium that extended up to the notch area (Fig. 3). Discreet new bone formation was seen in the notch area and the rest of the defect was filled with fibrous connective tissue rich in vessels and without inflammatory reaction (Fig. 3).

In the test defects, the junctional epithelium was observed coronally to the areas of new cementum and not interposed between the bioactive glass particles and the root surface (Fig. 4). A regular cementum layer was seen deposited within the notch and a thin cementum layer was observed coronally to this area, where the insertion of functionally oriented connective fibers was also observed (Fig. 5). There was new bone formation in the apical third and in the notch, with a greater amount of newly formed bone near the defect walls. The bioactive glass particles were distributed from the base up to the limit between the middle and coronal thirds. There were also particles with osteoid tissue

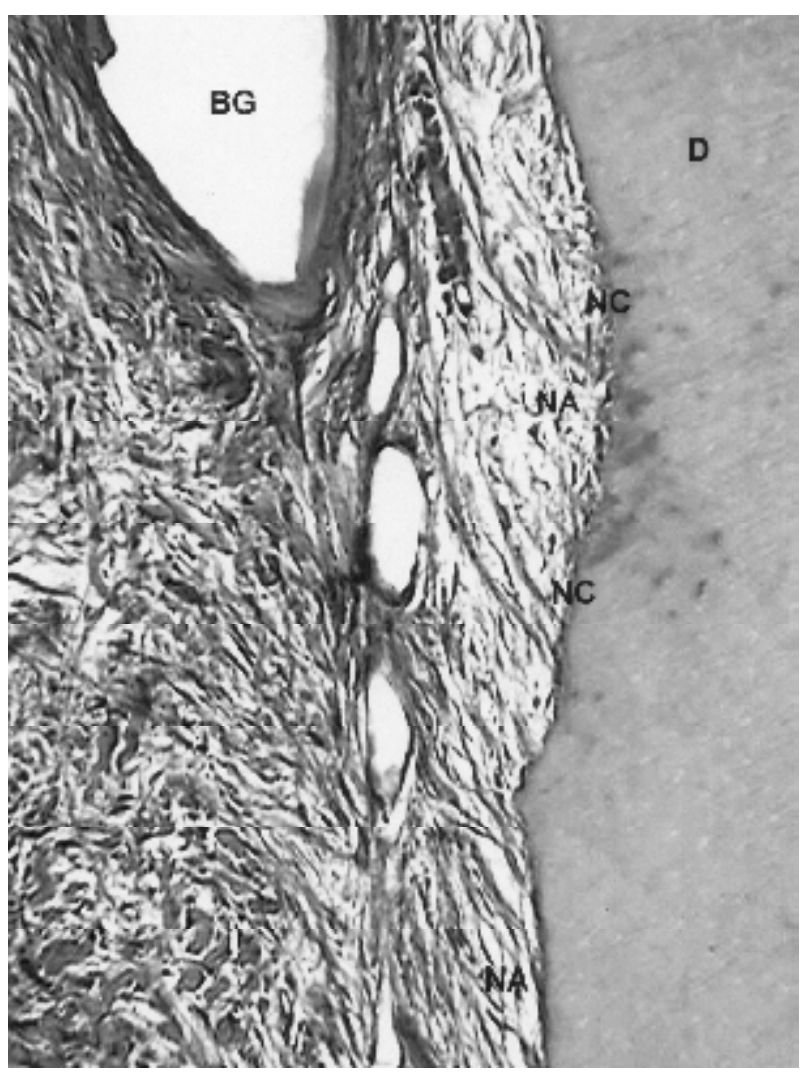

Figure 5. Histologic section of the test defect at 90 days. Deposit of a thin cementum layer where the insertion of functionally oriented connective fibers is observed. Masson trichrome stain (original magnification X56). $\mathrm{NC}=$ new cementum; $\mathrm{NA}=$ new attachment; $\mathrm{D}=$ dentin; $\mathrm{BG}=$ bioactive glass particle. formation in the middle third adjacent to the root surface, distant from the bone walls (Figs. 4 and 6). Surrounding the bone walls there was advanced replacement of bioactive glass particles by new bone, which denoted an intense osteoblastic activity identified by the presence of cuboid-shaped osteoblasts on the newly formed bone surface.

\section{Histomorphometry}

At 50 days, the mean distance from the most apical portion of the junctional epithelium to the notch on the defect base was $2.17 \pm 0.50 \mathrm{~mm}$ and $3.69 \pm 0.07$ $\mathrm{mm}$ in the control and test sites, respectively. At 90 days, this distance was $1.70 \pm 0.68 \mathrm{~mm}$ and $2.88 \pm 0.42$ $\mathrm{mm}$, respectively.

The mean distance from the notch on the defect base to the most coronal portion of the newly formed

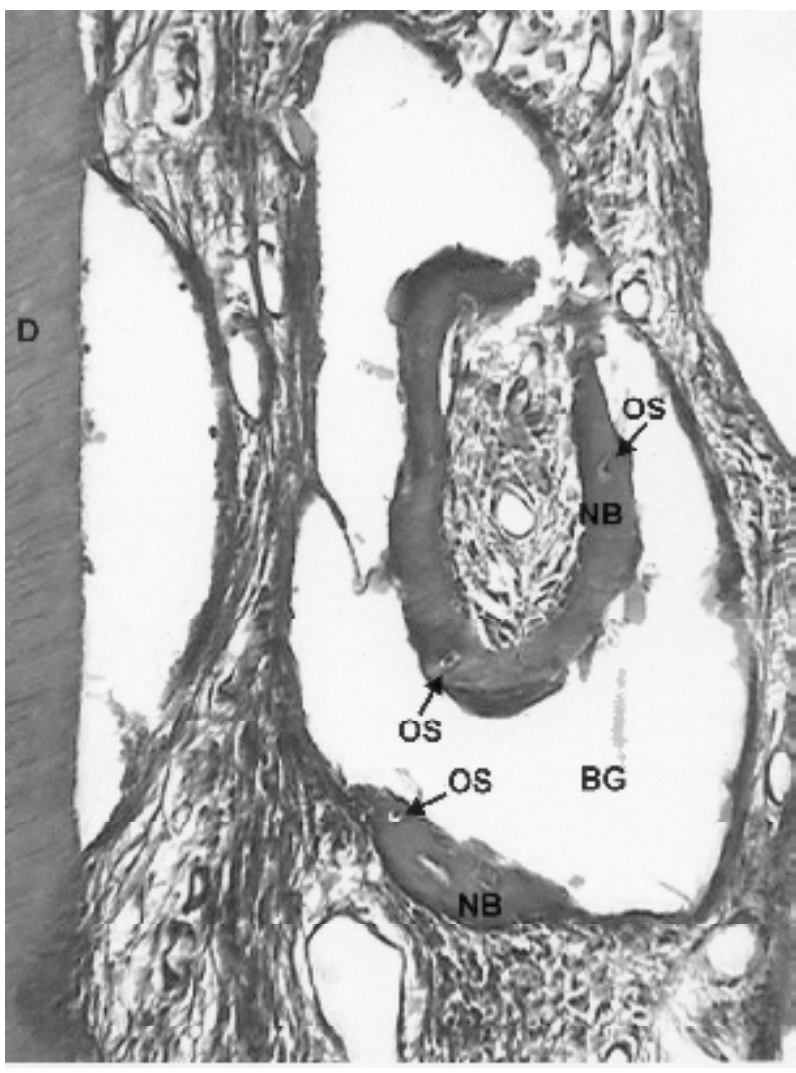

Figure 6. Greater magnification of the inset on Figure 4. New bone $(\mathrm{NB})$ in the bioactive glass particles (BG) in the middle third adjacent to root surface, distant from the bone walls. Masson trichrome stain (original magnification X56). D = dentin; Arrows $=$ osteocytes 
cementum at 50 days was $1.51 \pm 0.92 \mathrm{~mm}$ (range 0.86 $2.17 \mathrm{~mm}$ ) in the control sites and $3.00 \pm 0.42 \mathrm{~mm}$ in the test sites. At 90 days, this distance was $0.97 \pm 1.36 \mathrm{~mm}$ (range $0.00-1.93 \mathrm{~mm}$ ) in the control sites and $2.45 \pm$ $0.39 \mathrm{~mm}$ in test sites.

\section{DISCUSSION}

In this study, we observed that the use of a bioactive glass did not cause any undesirable reaction, showing biocompatibility with both connective and bone tissues. No foreign body reactions indicating toxicity were observed, which is in agreement with the findings of several in vitro (5) and histologic investigations in animals $(2,11)$.

Karatzas et al. (12), in a histologic study in monkeys, reported that the greatest contributions of a bioactive glass (particle size ranging from 90 to 710 $\mu \mathrm{m}$ ) in periodontal regeneration were its incorporation into the connective tissue, formation of a new insertion and inhibition of apical migration of the junctional epithelium. However, Nevins et al. (13) observed healing by long junctional epithelium in intrabony defects treated with similar bioactive glass in humans. In the present study, the tested bioactive glass showed an inhibitory property on the apical migration of the junctional epithelium. It was observed that in the sites treated with the bioactive glass, the junctional epithelium migrated apically to the level of the particles most coronally located inside the defect, not surpassing this point (Figs. 2 and 4).

The effects of bioactive glass on cellular activity can contribute to inhibition of apical migration of the junctional epithelium. Researchers have tried to explain the mechanism involved in this phenomenon based on the fact that when a bioactive glass is implanted in vivo, the $\mathrm{pH}$ of the site increases close to 10 , a layer rich in silica gel is formed on the surface of the particles and a subsequent calcium phosphate layer is formed by the interaction between calcium and phosphate from the bioactive glass and tissue fluids. The calcium phosphate layer is composed of hydroxycarbonate apatite that is chemically and structurally equivalent to bone mineral composition. This reaction occurs within few minutes of implantation and the osteogenic cells and collagen fibers colonize the surface of the bioactive glass, being incorporated into this layer (14). The collagen that attaches to the bioactive glass surface and is embedded into the hydroxycarbonate apatite extends apically to the junctional epithelium, thus inhibiting its apical migration (15). Its superficial bioactivity may stimulate a rapid formation of a connective tissue seal that is supposed to have the ability to block the epithelium migration and allow for repopulation of the previously contaminated area by periodontal ligament cells. However, in vitro studies have reported that the inhibition of epithelial migration results from a molecular interaction among epithelial cells, integrins and extracellular matrix (16). Integrins belong to the family of cellular adhesion molecules and act as cellsurface receptors for different molecules in the extracellular matrix and play a role in the development and maintenance of cell-cell and cell-matrix extracellular interactions. This includes, within the epithelium, adhesion of epithelium basal cells to the basal lamina, adhesion of one cell to another and epithelium proliferation, differentiation, apoptosis and migration (16). The real mechanism of blocking the migration of the junctional epithelium by bioactive glass needs further molecular investigation because this material yields a series of effects on cell activity and may cause this type of interaction $(1,14,15)$.

Clinically, the inhibition of epithelial migration can be identified by the decrease of probing depth and gain of clinical insertion, as observed in a previous study (8), in which 21 intrabony defects were treated with debridement plus bioactive glass graft and 17 were treated only with debridement.

In the present study, a regular layer of cementum could be observed in the notch area on the root surface in the test defects, with inhibition of apical migration of the junctional epithelium. This layer was thinner coronally, but there was insertion of functionally oriented connective tissue fibers indicating new connective tissue attachment. The new insertion could be identified by the existence of cementum deposition with connective fibers functionally attached and consequent inhibition of apical migration of the junctional epithelium. This newly formed insertion was greater in the defects treated with bioactive glass than in the debrided sites, which showed repair by long junctional epithelium. This is in agreement with other histologic and clinical studies that compared sites treated with homogeneous or alloplastic grafts to those treated with debridement (12).

At both 50 and 90 days (and in both test and 
control sites), new bone formation was more concentrated at the base of the defects. However, the test sites showed new bone formation on the bioactive glass particles that were located distant from the defect walls (Figs. 4 and 6). This may indicate that the graft material led to bone repair not only by an osseoconductive property, but also by cellular differentiation in the internal chamber of the particles because this bone had no connection with the pre-existing one. There was active deposit of osteoid matrix directly on the surface of the particles. These areas of new bone formation can act as nuclei for subsequent bone repair. This property, called osseostimulation by Schepers and Ducheyne (17), is different from osseoinduction or osseoconduction and can be defined as the capacity of an osseoconductive material to stimulate new bone deposition on its surface. This new bone does not maintain any connection with remnant bone or with newly formed bone.

The positive effect of bioactive glass on osteoblasts has been demonstrated in vitro and in vivothrough the positive effect of the calcium phosphate layer on bone matrix production (18).

In conclusion, the bioactive glass tested in this experiment had better healing potential than debridement only. The bioactive glass showed a promising inhibition of apical migration of the junctional epithelium and consequently greater cementum deposition on the radicular surface of 2-wall intrabony defects in monkeys. The replacement of bioactive glass particles by new bone occurred due not only to an osseoconductive property, but also to an osseostimulatory capacity. Future investigations should evaluate this potential comparatively or together with other grafting materials, regenerative techniques and biological modifiers, as well as assess the longitudinal stability of the new attachment.

\section{RESUMO}

A proposta desse estudo foi avaliar histologicamente a eficácia de um vidro bioativo com pequena variação de tamanho de partículas (Biogran) na cicatrização periodontal de defeitos infra-ósseos de 2 paredes em macacos. Os defeitos foram feitos na mesial dos segundos pré-molares direito e esquerdo de 4 macacos, a seguir foram preenchidos com guta-percha e, após 15 dias, foram debridados e preenchidos naturalmente com coágulo (controle) ou com vidro bioativo (teste). Nos sítios-controle, o epitélio juncional migrou até a base do defeito. A formação de novo cemento foi mais significante nos defeitos-teste. Ambos os tipos de defeitos, controle e teste, apresentaram formação de novo osso na área da base dos defeitos. Os defeitos-teste apresentaram deposição de novo osso ao redor e dentro de partículas de vidro bioativo localizadas no terço médio, distantes das paredes do defeito. A análise histológica demonstrou que o vidro bioativo com partículas de 300 a $355 \mu \mathrm{m}$ favoreceu nova inserção periodontal. Concluiu-se que o vidro bioativo testado teve melhor potencial de cura que o debridamento. O material enxertado mostrou promissora inibição da migração apical do epitélio junctional e maior deposição de cemento na superfície radicular em defeitos infra-ósseos A substituição das partículas de vidro bioativo por novo osso ocorreu devido não apenas a uma atividade osteo-condutora, mas também a uma capacidade osteoestimuladora. Futuras investigações devem avaliar esse potencial comparativamente a outros materiais de enxerto, técnicas regenerativas e modificadores biológicos, assim como, avaliar longitudinalmente a estabilidade dessa nova inserção.

\section{ACKNOWLEDGEMENTS}

The authors are grateful to the Primate Center of the State University of São Paulo (UNESP/Araçatuba) and CAPES (Government Scholarship and Funding).

\section{REFERENCES}

1. Matsuda T, Davies JE. The in vitro responses of osteoblasts to bioactive glass. Biomaterials 1987;8:275-284.

2. Hench LL, Paschall HA. Direct chemical bond of bioactive glassceramic materials to bone and muscle. J Biomed Mater Res (Symposium) 1973;4:25-42.

3. Hench LL. Special report: the interfacial behavior of biomaterials. J Biomed Mater Res 1980;14:803-811.

4. Matsuda T, Yamauchi K, Ito G. The influence of bioglass on the growth of fibloblasts. J Biomed Mater Res 1987;21:499-507.

5. Hench LL, Paschall HA. Histochemical responses at a biomaterial's interface. J Biomed Mater Res 1974;5:49-64.

6. Zamet JS, Darbar UR, Griffiths GS, Bulman JS, Bragger U, Burgin W, Newman HN. Particulate bioglass as a grafting material in the treatment of periodontal intrabony defects. J Clin Periodontol 1997;24:410-418.

7. Low SB, King CJ, Krieger J. An evaluation of bioactive ceramic in the treatment of periodontal osseous defects. Int J Periodontics Restorative Dent 1997; 17:358-367.

8. Park JS, Suh JJ, Choi SH, Moon IS, Cho KS, Kim CK, Chai JK. Effects of pretreatment clinical parameters on bioactive glass implantation in intrabony periodontal defects. J Periodontol 2001;72:730-740

9. Schepers EJ, Ducheyne P, Barbier L, Schepers S. Bioactive glass particles of narrow size range: a new material for the repair of bone defects. Implant Dent 1993;2:151-156.

10. Morse A. Formic acid-sodium citrate decalcification and butyl alcohol dehydration of teeth and bone sectioning in paraffin. $\mathbf{J}$ Dent Res 1945;24:143.

11. Wilson J, Clark AE, Hall M, Hench LL. Tissue response to bioglass endosseous ridge maintenance implants. J Oral Implantol 1993;19:295-302.

12. Karatzas S, Zavras A, Greenspan D, Amar S. Histologic observations of periodontal wound healing after treatment with Perioglas in nonhuman primates. Int $\mathbf{J}$ Periodontics Restorative Dent 
1999; 19:489-499

13. Nevins ML, Camelo M, Nevins M, King CJ, Oringer RJ, Schenk RK, Fiorellini JP. Human histologic evaluation of bioactive ceramic in the treatment of periodontal osseous defects. Int J Periodontics Restorative Dent 2000;20:459467.

14. Hench LL, Wilson J. Surface-active biomaterials. Science 1984;226:630-636.

15. Wilson J, Low SB. Bioactive ceramics for periodontal treatment: comparative studies in the Patus Monkey. J Appl Biomater 1992;3:123-129.

16. Gräber HG, Conrads G, Wilharm J, Lampert F. Role of interac- tions between integrins and extracellular matrix component in healthy epithelial tissue and establishment of a long junctional epithelium during periodontal wound healing: A review. J Periodontol 1999;70:1511-1522.

17. Schepers EJG, Ducheyne P. Bioactive glass particles of narrow size range for the treatment of oral bone defects: a 1-24 month experiment with several materials and particles sizes and size range. J Oral Rehabil 1997;24:171-181.

18. Vrouwenveldel WCA, Groot CG, Groot K. Histological and biochemical evaluation of osteoblasts cultured on bioactive glass, hydroxyapatite, titanium alloy, and stainless steel. J Biomed Mater Res 1993;27:465-475. 